\title{
Agricultural land-use change in a Mexican oligotrophic desert depletes ecosystem stability
}

\author{
Natali Hernández-Becerra ${ }^{1}$, Yunuen Tapia-Torres ${ }^{2}$, Ofelia Beltrán-Paz $^{1}$, Jazmín Blaz $^{3}$, Valeria Souza ${ }^{3}$, \\ Felipe García-Oliva ${ }^{\text {Corresp. } 1}$ \\ ${ }^{1}$ Laboratorio de biogeoquímica de suelos, Instituto de Investigaciones en Ecosistemas y Sustentabilidad, UNAM, Morelia, Michoacán, Mexico \\ 2 ENES Unidad Morelia, Universidad Nacional Autónoma de México, Morelia, Michoacán, Mexico \\ 3 Instituto de Ecología, Universidad Nacional Autónoma de México, Mexico, Mexico, Mexico \\ Corresponding Author: Felipe García-Oliva \\ Email address: fgarcia@cieco.unam.mx
}

Background. Global demand for food has led to increased land-use change, particularly in dry land ecosystems, which has caused several environmental problems due to the soil degradation. In the Cuatro Cienegas Basin (CCB), alfalfa production irrigated by flooding impacts strongly on the soil. Methods. In order to analyze the effect of such agricultural land-use change on soil nutrient dynamics and soil bacterial community composition, this work examined an agricultural gradient within the CCB which was comprised of a native desert grassland, a plot currently cultivated with alfalfa and a former agricultural field that had been abandoned for over 30 years. For each site, we analyzed $\mathrm{C}, \mathrm{N}$ and $\mathrm{P}$ dynamic fractions, the activity of the enzyme phosphatase and the bacterial composition obtained using 16S rRNA clone libraries. Results. The results showed that the cultivated site presented a greater availability of water and dissolved organic carbon, these conditions promoted mineralization processes mediated by heterotrophic microorganisms, while the abandoned land was limited by water and dissolved organic nitrogen. The low amount of dissolved organic matter promoted nitrification, which is mediated by autotrophic microorganisms. The microbial $\mathrm{N}$ immobilization process and specific phosphatase activity were both favored in the native grassland. As expected, differences in bacterial taxonomical composition were observed among sites. The abandoned site exhibited similar compositions than native grassland, while the cultivated site differed. Discussion. The results suggest that the transformation of native grassland into agricultural land induces drastic changes in soil nutrient dynamics as well as in the bacterial community. However, with the absence of agricultural practices, some of the soil characteristics analyzed slowly recovers their natural state. 
1 Agricultural land-use change in a Mexican oligotrophic desert depletes ecosystem stability.

2

3 Natali Hernández-Becerra ${ }^{1}$, Yunuen Tapia-Torres ${ }^{2}$, Ofelia Beltrán ${ }^{1}$, Jazmín Blaz-Sánchez ${ }^{3}$,

$4 \quad$ Valeria Souza $^{3}$ and Felipe García-Oliva ${ }^{*}$

$5 \quad{ }^{1}$ Instituto de Investigaciones en Ecosistemas y Sustentabilidad, Universidad Nacional Autónoma

6 de México, Morelia, Michoacán, 58190 México. fgarcia@cieco.unam.mx. Tel.: 52-4433222715.

7 2Escuela Nacional de Estudios Superiores Morelia, Universidad Nacional Autónoma de México,

8 Campus Morelia, Michoácan, 58190 Mexico.

9 Instituto de Ecología, Departamento de Ecología Evolutiva, Universidad Nacional Autónoma de

10 México, México DF, 04510 México.

$11 *$ : Corresponding author 


\section{Abstract}

Background. Global demand for food has led to increased land-use change, particularly in dry land ecosystems, which has caused several environmental problems due to the soil degradation. In the Cuatro Cienegas Basin (CCB), alfalfa production irrigated by flooding impacts strongly on the soil. Methods. In order to analyze the effect of such agricultural land-use change on soil nutrient dynamics and soil bacterial community composition, this work examined an agricultural gradient within the $\mathrm{CCB}$ which was comprised of a native desert grassland, a plot currently cultivated with alfalfa and a former agricultural field that had been abandoned for over 30 years. For each site, we analyzed $\mathrm{C}, \mathrm{N}$ and $\mathrm{P}$ dynamic fractions, the activity of the enzyme phosphatase and the bacterial composition obtained using 16S rRNA clone libraries. Results. The results showed that the cultivated site presented a greater availability of water and dissolved organic carbon, these conditions promoted mineralization processes mediated by heterotrophic microorganisms, while the abandoned land was limited by water and dissolved organic nitrogen. The low amount of dissolved organic matter promoted nitrification, which is mediated by autotrophic microorganisms. The microbial $\mathrm{N}$ immobilization process and specific phosphatase activity were both favored in the native grassland. As expected, differences in bacterial taxonomical composition were observed among sites. The abandoned site exhibited similar compositions than native grassland, while the cultivated site differed. Discussion. The results suggest that the transformation of native grassland into agricultural land induces drastic changes in soil nutrient dynamics as well as in the bacterial community. However, with the absence of agricultural practices, some of the soil characteristics analyzed slowly recovers their natural state. 
38 Key words: bacteria community, Medicago sativa L., microbial activity, resilience, soil nutrients

\section{INTRODUCTION}

40 Rising global food demand due to population growth has caused an increase in rates of land-use

41 change to agricultural production in dry ecosystems (Lepers et al., 2005; Reynolds et al., 2007).

42 This has led to several environmental problems, including deforestation, habitat fragmentation,

biodiversity reduction, changes to global biogeochemical cycles, water and soil contamination

and degradation (Reynolds et al., 2007; Rey-Benayas \& Bullock, 2012). In these perturbed dry

lands, the main drivers of desertification are soil nutrient losses caused mainly by erosion, soil

salinization and the reduction of soil water retention capacity through the deterioration of soil

physical properties (D'Odorico et al., 2013). This soil degradation reduces agricultural

productivity and the fields are eventually abandoned.

The main characteristics of intensive agriculture that affect soil properties is the reduction of organic matter inputs, soil tillage, fertilization and irrigation (McLauchlan, 2006). It has been reported that soil organic matter (SOM) is reduced by $16-77 \%$, as a consequence of agriculture (Murty et al., 2002). This is mainly through the decrease in organic matter inputs and the increase in soil organic decomposition because of increased tillage and soil temperatures (TrasarCepeda et al., 2008; Beheshti et al., 2012). The practice of tillage disrupts the physical properties of the soil, affecting soil water and nutrient dynamics (Six et al., 1999; Zeleke et al., 2004; Bronick \& Lal, 2005). Fertilization with nitrogen, mainly in the form of ammonium, promotes faster nitrification and the release of $\mathrm{H}^{+}$ions into the soil solution, thus lowering soil $\mathrm{pH}$ (Moore et al., 2000) and the continuous irrigation increases the leaching of salts through the soil profile (Raiesi, 2004). However, when agricultural fields are abandoned, some salts accumulate in the topsoil, promoting salinization, a process that is favored in desert ecosystems (Rietz \& Haynes, 2003; Pan et al., 2012). Furthermore, plant succession is slower in desert ecosystems than in wet 
62 tropical ecosystems; for example, recovery of vegetation requires at least 40 years in the former,

63 while in the latter it can be achieved in less than 10 years (Lesschen et al., 2008; Wang et al.,

64 2011).

65 Agriculture also has an effect on the composition of the soil microbial community. For instance,

66 some changes in microbial composition have been reported as a result of agricultural land-use in

67 tropical (Waldrop et al., 2000) as well as desert (Ding et al., 2013) and Mediterranean

68 ecosystems (García-Orenes et al., 2013). However, the effect on soil microbial diversity is

69 unclear; some studies have described increases in biodiversity (Jangid et al., 2008) while others

70 have reported decreases (Lupwayi et al., 1998). Chaudhry et al. (2012) found higher soil

71 microbial diversity in agricultural fields managed with organic rather than chemical fertilization.

72 These authors found that the composition of the bacterial community in the organically fertilized

73 soil was dominated by the phyla Proteobacteria, Bacteroidetes and Gemmatimonadetes, while

74 the groups Actinobacteria and Acidobacteria were predominant in the chemically fertilized soil.

75 The dominant phyla in the organically fertilized soil have been associated with high nutrient

76 availability, whereas the Acidobacteria have been related to nutrient-poor soils (Fierer et al.,

77 2007). The effect of long-term agricultural management on soil microbial communities is

78 similarly unclear; in some studies, even after 9 years of abandonment, the soil microbial

79 composition remains similar to that of the cultivated soil (Buckley \& Smith, 2001). However, an

80 agricultural field abandoned for over 45 years presented a soil microbial community that was

81 similar to one in soil with native vegetation cover (Buckley \& Smith, 2003). These results

82 demonstrate the need for further study in order to understand the effect of succession of

83 agriculture management upon the composition of the soil microbial community. 
84 The worldwide area of degraded agriculture fields was estimated to be $12,400,000 \mathrm{~km}^{2}$ in 2007

85 (Rey-Benayas \& Bullock, 2012), of which $20 \%$ corresponded to dry ecosystems (Lepers et al.,

86 2005; Reynolds et al., 2007). In Mexico, around $121 \mathrm{~km}^{2}$ and $45 \mathrm{~km}^{2}$ of grassland were

87 converted to agriculture and abandoned lands, respectively, between 2005 and 2010 (Colditz et

88

al., 2014). For this reason, evaluation of the capacity for soil restoration in the cultivated fields of dry lands is a priority for crop production and ecosystem conservation. This capacity can be evaluated in the context of ecosystem stability, which has two main components: resistance and resilience (Pimm, 1984). The former is the capacity of the ecosystem to face a disturbance without undergoing structural changes, while the latter reflects the time required for the ecosystem to return to its pre-disturbance condition (Pimm ,1984). Orwin and Wardle (2004) proposed indices for evaluating these two attributes of soil stability, which are accurate for providing a relative quantitative measurement when comparing soil conditions under perturbation. The quantitative measure of soil stability allows evaluation of the magnitude of soil degradation and its capability for restoration.

In the Cuatro Cienegas basin (CCB) in Mexico, alfalfa (Medicago sativa L.) production with gravity irrigation involves flooding the fields with oasis water that is channeled through open canals for hundreds of $\mathrm{km}$. This practice unequivocally threatens the sustainability of the $\mathrm{CCB}$ wetland and degrades the soil and vegetation. In order to analyze the effect of such agricultural land-use on the soil nutrient dynamics $(\mathrm{C}, \mathrm{N}$ and $\mathrm{P})$ and composition of the soil bacterial community, we examined an agricultural gradient within the $\mathrm{CCB}$ composed of three sites with the same soil type but under contrasting management: a native desert grassland, a plot with an alfalfa crop and a former agricultural field that had been abandoned for over 30 years. We predicted that the alfalfa production disrupts the mechanisms of soil nutrient transformation and 
107 strongly affects the composition of the soil bacteria. To test these hypotheses, we analyzed C, N

108 and $\mathrm{P}$ dynamic fractions and used this data to calculate the homeostasis of the microbial

109 community. The enzymatic activity of alkaline phosphatase was also quantified and bacterial

110 composition was determined through the use of 16S rRNA clone libraries.

112 MATERIAL AND METHODS

113 Site description

114 This study was carried out in the Cuatro Cienegas basin (CCB; $26^{\circ} 50^{\prime} \mathrm{N}$ and $\left.102^{\circ} 8^{\prime} \mathrm{W}\right)$ at 740

115 masl, in the Chihuahuan desert in Mexico. The climate is seasonally arid with an average annual

116 temperature of $21^{\circ} \mathrm{C}$ and annual precipitation of $252 \mathrm{~mm}$ (http://smn.cna.gob.mx/). Jurassic-era

117 gypsum is the dominant parent material on the western side of the basin, while Jurassic-era

118 limestone dominates on the eastern side (McKee, Jones \& Long, 1990). According to the WRB

119 classification (2007), the predominant soils are Gypsisol and Calcisol on the western and eastern

120 sides of the basin, respectively. The soil within the CCB is characterized by low P concentrations

121 (ranging between 70-200 $\mathrm{g} \mathrm{g}^{-1}$ ). These values are lower than the $\mathrm{P}$ values of other soils within

122 the Chihuahuan desert (500-1000 $\mu \mathrm{g} \mathrm{g}^{-1}$; Tapia-Torres \& García-Oliva, 2013). The main

123 vegetation types are halophyte-grassland dominated by Sporobolus airoides (Poaceae) and desert

124 scrub dominated by species from the Euphorbiaceae and Zygophyllaceae families (Perroni et al.,

125 2014). Agricultural activity in the CCB began in the early decades of the $20^{\text {th }}$ century but has

126 increased in the last 30 years and it mainly consists on the production of alfalfa for cattle fodder.

127 Alfalfa (Medicago sativa L.) is growth by flooding the fields and introducing large quantities of

128 fertilizer. In some years, sorghum (Sorghum spp.) is cultivated, but the alfalfa cultivation 
129 dominates the agricultural surface (INEGI, 2011). However, these fields must eventually be

130 abandoned due to degradation of the soil, mainly through salinization.

132 Field sampling

133 Sampling sites were located on the eastern side of the CCB. An agricultural gradient was

134 established comprising three sites of shared soil type (Calcisol) but contrasting management all

135 located in flat areas: native desert grassland, a plot cultivated with alfalfa and a former

136 agricultural field that had been abandoned for over 30 years. The native desert grassland was in

137 the Pozas Azules reserve $\left(26^{\circ} 49^{\prime} 30^{\prime \prime} \mathrm{N}\right.$ and $\left.102^{\circ} 1^{\prime} 27^{\prime \prime} \mathrm{W}\right)$ where Sporobolus airoides is the

138 dominant plant species (Tapia-Torres et al., 2015a). The cultivated alfalfa field was located in

139 the Cuatro Cienegas ejido $\left(26^{\circ} 58^{\prime} 47^{\prime \prime} \mathrm{N}\right.$ and $\left.102^{\circ} 02^{\prime} 13^{\prime \prime} \mathrm{W}\right)$ and covered an area of 2.7 ha

140 with high fertilizer inputs and irrigation by flooding every month. The plot was fertilized with

141 monoammonium phosphate (11-52-00) dissolved in the water for irrigation. The water for

142 irrigation had a $\mathrm{pH}$ value of 8.5 with a high electrical conductivity $\left(150 \mathrm{mS} \mathrm{m}^{-1}\right)$. This alfalfa plot

143 has been under cultivation for 20 consecutive years and the alfalfa is harvested every month.

144 Finally, the abandoned field was also in the Cuatro Cienegas ejido $\left(26^{\circ} 58^{\prime} 57^{\prime \prime} \mathrm{N}\right.$ and $102^{\circ} 01^{\prime} 8^{\prime \prime}$

145 W) and presented minimum plant cover (less than 30\% of the area). Oscar Sánchez Liceaga,

146 Héctor Castillo González, the personnel of APFF Cuatro Cienegas (CONANP) and the people in

147 charge of Rancho Pozas Azules (PRONATURA) gave us the permission to collect soil samples

148 on their respective properties. At each site, a $100 \times 50 \mathrm{~m}$ plot was delimited and then divided into

14910 sections at a distance of $10 \mathrm{~m}$ apart. A random sampling transect was then established in each

150 section, with topsoil samples taken to a depth of $15 \mathrm{~cm}$ at ten sampling points (every five meters)

151 in September 2011; these samples were then mixed to form one composite sample. In total, 10 
152 such composite samples were taken in each plot. Soil for biogeochemical and enzymatic activity

153 analysis was stored in black plastic bags and refrigerated at $4{ }^{\circ} \mathrm{C}$. In order to characterize the

154 bacterial community at each site, $100 \mathrm{~g}$ of composite samples were immediately stored in liquid

155 nitrogen until subsequent DNA extraction.

156 Laboratory analyses

157 Soil nutrient and enzymatic analyses

158 Soil $\mathrm{pH}$ was measured in deionized water (1:2 w:v) using a digital $\mathrm{pH}$ meter (Corning) and soil

159 electrical conductivity was measured by conductivity meter (Hannan Instruments Inc.; Houston,

160 USA). A subsample (100 g) was oven-dried at $75^{\circ} \mathrm{C}$ to constant weight for soil moisture

161 determination using the gravimetric method in order to adjust for water content when expressing

162 nutrient concentration on the basis of dry soil mass. All C forms analyzed in all samples were

163 determined in a total carbon analyzer (UIC model CM5012, Chicago, USA), while the N and P

164 forms analyzed were determined colorimetrically in a Bran-Luebbe Auto analyzer 3

165 (Norderstedt, Germany). Prior to the total soil nutrient analyses, soil samples were dried and

166 ground with a pestle and mortar. Total carbon (TC) and inorganic carbon (IC) were determined

167 by combustion and coulometric detection (Huffman, 1977). Total organic carbon (OC) was

168 calculated as the difference between TC and IC. For total N (TN) and total P (TP)

169 determination, samples were acid digested with $\mathrm{H}_{2} \mathrm{SO}_{4}, \mathrm{H}_{2} \mathrm{O}_{2}, \mathrm{~K}_{2} \mathrm{SO}_{4}$ and $\mathrm{CuSO}_{4}$ at $360^{\circ} \mathrm{C}$. Soil

$170 \mathrm{~N}$ was determined by the macro-Kjeldahl method (Bremmer, 1996), while $\mathrm{P}$ was determined by

171 the molybdate colorimetric method following ascorbic acid reduction (Murphy \& Riley, 1962).

172 Available, dissolved and microbial nutrient forms were extracted from field moist soil samples.

173 Available inorganic $\mathrm{N}\left(\mathrm{NH}_{4}{ }^{+}\right.$and $\left.\mathrm{NO}_{3}{ }^{-}\right)$was extracted from $10 \mathrm{~g}$ of fresh soil subsamples with

$1742 \mathrm{M} \mathrm{KCl}$, followed by filtration through a Whatman No. 1 paper filter (Robertson et al., 1999) 
175 and determined colorimetrically by the phenol-hypochlorite method. Available (inorganic) and

176 labile (organic) $\mathrm{P}$ was determined by extraction with $0.5 \mathrm{M} \mathrm{NaHCO}_{3}$ at $\mathrm{pH} 8.5$ according to

177 Hedley sequential P fractionation (Tiessen \& Moir, 1993) and quantified as described above for

178 orthophosphate.

179 Dissolved nutrients were extracted with deionized water after shaking for 45 min and filtering

180 through a Millipore $0.42 \mu \mathrm{m}$ filter (Jones \& Willet, 2006). Prior to acid digestion, one aliquot of

181 the filtrate was used to determine dissolved ammonium $\left(\mathrm{DNH}_{4}^{+}\right)$and inorganic $\mathrm{P}$ (IP) in

182 deionized water extract. Total dissolved nitrogen (TDN) was digested using the macro-Kjeldahl

183 method. Total dissolved P (TDP) was also acid digested and determined by colorimetry. Total

184 dissolved carbon (TDC) was measured with an Auto Analyzer of carbon (TOC CM 5012)

185 module for liquids (UIC-COULOMETRICS). Inorganic dissolved carbon (IDC) was determined

186 in an acidification module CM5130. Dissolved organic carbon (DOC), dissolved organic

187 nitrogen (DON) and dissolved organic phosphorous (DOP) were calculated as the difference

188 between total dissolved forms and inorganic dissolved forms.

189 Microbial $\mathrm{C}\left(\mathrm{C}_{\text {mic }}\right), \mathrm{N}\left(\mathrm{N}_{\text {mic }}\right)$ and $\mathrm{P}\left(\mathrm{P}_{\text {mic }}\right)$ concentrations were determined by the chloroform

190 fumigation extraction method (Vance et al., 1987). Fumigated and non-fumigated samples were

191 incubated for $24 \mathrm{~h}$ at $25^{\circ} \mathrm{C}$ and constant moisture. Microbial $\mathrm{C}$ was extracted from fumigated and

192 non-fumigated samples with $0.5 \mathrm{M} \mathrm{K}_{2} \mathrm{SO}_{4}$ and filtered through Whatman No. 42 filters (Brookes

193 et al., 1985). The concentration of $\mathrm{C}$ was measured in each extract as total and inorganic $\mathrm{C}$

194 concentration by the method described before. Microbial C was calculated by subtracting the

195 extracted carbon in non-fumigated samples from that of fumigated samples and dividing the

196 result by a $\mathrm{K}_{\mathrm{EC}}$ value (the extractable part of microbial biomass C) of 0.45 (Joergensen, 1996).

197 Microbial $\mathrm{N}$ was extracted with the same procedure used for $\mathrm{C}_{\mathrm{mic}}$, but the extract was filtered 
198 through Whatman No. 1 paper. The filtrate was acid digested and determined as TN by Macro-

199 Kjeldahl method (Brookes et al., 1985). Microbial $\mathrm{N}$ was calculated as for $\mathrm{C}_{\text {mic }}$, but divided by a

$200 \mathrm{~K}_{\mathrm{EN}}$ value (the extractable part of microbial biomass $\mathrm{N}$ after fumigation) of 0.54 (Joergensen \&

201 Muller, 1996). Microbial $\mathrm{P}$ was extracted using $\mathrm{NaCO}_{3} 0.5 \mathrm{M}$ at $\mathrm{pH} 8.5$, after which the

202 fumigation-extraction technique involving chloroform was performed (Cole et al. 1978).

203 Microbial $\mathrm{P}$ was calculated as for $\mathrm{C}_{\mathrm{mic}}$ and $\mathrm{N}_{\text {mic }}$ and converted using a $\mathrm{K}_{\mathrm{P}}$ value (the extractable

204 part of microbial biomass P after fumigation) of 0.4 (Lathja et al.,1999). Microbial P was

205 determined colorimetrically by the molybdate-ascorbic acid method using an Evolution 201

206 Thermo Scientific Inc. spectrophotometer (Murphy \& Riley, 1962). Finally, $\mathrm{C}_{\text {mic }}, \mathrm{N}_{\text {mic }}$ and $\mathrm{P}_{\text {mic }}$

207 values were normalized on a dry soil basis.

208 Because, $\mathrm{P}$ is considered the most limited soil nutrient in the east-side of the CCB (Tapia-Torres

209 et al., 2015), alkaline phosphatase activity was analyzed colorimetrically using $\rho$-nitrophenol

210 ( $\rho N P$ ) substrates, according to Tabatabai and Bremner (1969) and Eivazi and Tabatabai, (1977).

211 For this analysis, $2 \mathrm{~g}$ of fresh soil and $30 \mathrm{ml}$ of modified universal buffer (MUB) at $\mathrm{pH} 9$ were

212 used for the exoenzyme extraction. Three replicates and one control (sample without substrate)

213 were prepared per sample. Three substrate controls (substrate without sample) were also

214 included per assay. We centrifuged the tubes after the incubation period and then $750 \mu 1$ of

215 supernatant was diluted in $2 \mathrm{ml}$ of deionized water and absorbance of $\rho$-nitrophenol ( $\rho \mathrm{NP})$

216 measured at $410 \mathrm{~nm}$ on an Evolution 201 Thermo Scientific Inc, spectrophotometer. Exoenzyme

217 activities were expressed as micromoles of $\rho$ NP formed per gram dry weight of soil per hour

$218\left(\mu \mathrm{mol} \rho \mathrm{NP}[\mathrm{g} \mathrm{SDW}]^{-1} \mathrm{~h}^{-1}\right)$. This value was standardized by $\mathrm{C}_{\text {mic }}$ concentration for expression as a

219 specific enzyme activity $\left(\mu \mathrm{mol} \rho \mathrm{NP}\left[\mathrm{mg} \mathrm{C}_{\mathrm{mic}}\right]^{-1} \mathrm{~h}^{-1}\right)$.

220 Molecular analyses 
221 Total DNA was extracted using the hydroxyapatite spin-column method (Purdy et al., 1996).

222 DNA molecular weight and quality were confirmed using agarose gel electrophoresis. The 16S

223 rRNA gene was amplified from each sample using a polymerase chain reaction (PCR) with the

224 universal primers F27 (5' AGAGTTTGATCMTGGCTCAG3') and R1492

225 (5'GGTTACCTTGTTACGACTT3'). Three independent PCRs were performed for each sample.

226 The PCR reactions were $50 \mu \mathrm{l}$ in volume and contained $2 \mu \mathrm{l}$ of DNA, $1 \mu \mathrm{l}$ PCR buffer $1 \mathrm{X}, 0.5$

$227 \mathrm{mM} \mathrm{MgCl} 2,0.2 \mathrm{mM}$ dNTP mixture, $0.2 \mathrm{mM}$ of each primer, 1 unit of platinum Taq DNA

228 Polymerase High Fidelity (Invitrogen), 5\% DMSO and $0.05 \mathrm{mg}$ of BSA. The PCR was

229 performed in a thermal cycler (MJ Research, Watertown, MA) under the following cycling

230 program: initial denaturation step at $94^{\circ} \mathrm{C}$ for $5 \mathrm{~min}$, then 30 cycles at $94{ }^{\circ} \mathrm{C}$ for $1 \mathrm{~min}, 52^{\circ} \mathrm{C}$ for

$2311 \mathrm{~min}$, and $72{ }^{\circ} \mathrm{C}$ for $1 \mathrm{~min} 20 \mathrm{sec}$, with a final extension step at $72{ }^{\circ} \mathrm{C}$ for $30 \mathrm{~min}$ and storage at 4

$232{ }^{\circ} \mathrm{C}$. The three reactions were pooled and purified in a $1 \%$ agarose gel using the QIAquick gel

233 extraction kit (Qiagen). The purified fragment was cloned into the vector PCR 2.1 and

234 transformed into Escherichia coli following the manufacturer's instructions (Invitrogen). Only

235 plasmids containing inserts were isolated for sequencing with the Montage Plasmid Miniprepkit

236 (Millipore). The insertion within the plasmids was sequenced with the Sanger method using the

237 vector-based primer 27F.

238

239 Data analysis

240 Stoichiometric homeostasis

241 The degree of community-level microbial $\mathrm{C}: \mathrm{N}$ and $\mathrm{C}: \mathrm{P}$ homeostasis $\left(\mathrm{H}^{\prime}\right)$ by soil microorganisms

242 was calculated with the formula proposed by Sterner and Elser (2002):

$243 \quad H^{\prime}=1 / m$ 
244 In equation (1), $m$ is the slope of $\log _{e} C: N_{R}$ (Carbon and Nitrogen in the resources) versus $\log _{e}$

$245 \mathrm{C}: \mathrm{N}_{\mathrm{B}}$ (Carbon and Nitrogen in the microbial biomass) or slope of $\log _{\mathrm{e}} \mathrm{C}: \mathrm{P}_{\mathrm{R}}$ (Carbon and

246 Phosphorus in the resources) versus $\log _{\mathrm{e}} \mathrm{C}: \mathrm{P}_{\mathrm{B}}$ (Carbon and Phosphorus in the microbial biomass)

247 scatterplot. $H^{\prime}>>1$ represents strong stoichiometric homeostasis, while $H^{\prime} \approx 1$ represents weak or

248 no homeostasis (Sterner \& Elser, 2002).

249 Resistance and resilience index

250 Nutrient concentration and enzymatic activity data were both analyzed for resistance and

251 resilience using the indices proposed by Orwin and Warlde (2004). The grassland site was

252 considered as the control $\left(\mathrm{C}_{0}\right)$, the cultivated site as the disturbance $\left(\mathrm{P}_{0}\right)$ and the abandoned plot

253 was used for measuring resilience 30 years after the cessation of agriculture management $\left(\mathrm{P}_{\mathrm{x}}\right)$.

254 Resistance (RS) was calculated as follows:

$255 \quad \mathrm{RS}=1-\left(\left(2\left|\mathrm{D}_{0}\right|\right) /\left(\mathrm{C}_{0}+\left|\mathrm{D}_{0}\right|\right)\right)$

256 In equation (2), $\mathrm{C}_{0}$ represents the control soil and $\mathrm{D}_{0}$ is the difference between $\mathrm{C}_{0}$ and the

257 disturbed plot $\left(\mathrm{P}_{0}\right)$. In addition, resilience $(\mathrm{RL})$ was calculated as follows:

$258 \quad \mathrm{RL}=\left(\left(2\left|\mathrm{D}_{0}\right|\right) /\left(\left|\mathrm{D}_{0}\right|+\left|\mathrm{D}_{\mathrm{X}}\right|\right)\right)-1$

259 In equation (3), $\mathrm{D}_{\mathrm{X}}$ is the difference between $\mathrm{C}_{0}$ and $\mathrm{P}_{\mathrm{X}}$. Both indexes are bounded by -1 and +1 ,

260 if the value is -1 means less resistance or resilience, while the +1 value means maximal

261 resistance or resilience.

262 Bioinformatics analysis

263 Sequencing quality evaluation as well as cloning vector removal were performed using the

264 sorftware PHRED (Ewing \& Green 1998). For processing and classification of the sequence

265 data, the open source software package Mothur (v 1.15.0; Schloss et al., 2009) was used.

266 Sequences were screened for potential chimeric reads using Chimera.slayer (Haas et al., 2011) 
267 and the linked SILVA template database. High-quality sequences were compared against the

268 SILVA database in order to obtain their taxonomic rank. A pairwise distance matrix was

269 calculated across the non-redundant sequences, and reads were clustered into operational

270 taxonomic units (OTUs) at 3\% distance, using the furthest neighbor method (Schloss \&

271 Handelsman, 2006). In addition, the Simpson and Shannon (H) indices, Chao species richness

272 estimator and rarefaction curves were estimated.

273 Statistical analysis.

274 One-way ANOVA was used to identify differences in nutrient concentrations and enzymatic

275 activity between the sites of the agricultural gradient (grassland, cultivated field and abandoned

276 field). Log-transformations were applied where the data deviated from normality. When

277 ANOVA indicated a significant site effect, mean comparisons were performed with Tukey's

278 multiple comparisons test (Von Ende, 1993).

279 Pearson correlations were used to explore relationships among soil parameters. Principal

280 Components Analysis (PCA) was conducted in order to group soil samples with active nutrients

281 forms (dissolved, available and microbial) and enzymatic activity. Similarly, Canonical Analysis

282 was conducted with soil nutrients (available, dissolved organic and $\mathrm{pH}$ ) as the independent

283 variables and nutrients within microbial biomass and phosphatase activity as dependent

284 variables. All analyses were performed using R software 2.10.1 (R Core Development Team, 285 2009).

286

287 RESULTS

288 Soil nutrients 
289 Soil nutrients. The abandoned and cultivated plots had the highest and the lowest soil $\mathrm{pH}$ and

290 soil electrical conductivity, respectively $(\mathrm{P}<0.0001$ and $\mathrm{P}=0.0002$ for $\mathrm{pH}$ and electrical

291 conductivity, respectively; Table 1). Total organic C, N and P concentrations differed among

292 management gradient plots. Total organic C was almost two times greater in the cultivated plot

293 than in the other two plots $(\mathrm{P}<0.0001$; Table 1), whereas the cultivated and grassland plots

294 presented the highest and the lowest $\mathrm{N}$ and $\mathrm{P}$ concentrations, respectively $(\mathrm{P}<0.001$ and

$295 \mathrm{P}<0.0001$ for $\mathrm{N}$ and $\mathrm{P}$, respectively; Table 1). As a consequence, the highest $\mathrm{C}: \mathrm{P}$ and $\mathrm{N}: \mathrm{P}$ ratios

296 were in the grassland plot $(\mathrm{P}<0.0001$ for both $\mathrm{C}: \mathrm{P}$ and $\mathrm{N}: \mathrm{P})$, while the $\mathrm{C}: \mathrm{N}$ ratio did not differ

297 among plots (Table 1). The cultivated plot presented higher DOC and DOP than the other two

298 plots $(\mathrm{P}<0.0001$ and $\mathrm{P}<0.001$ for DOC and DOP, respectively), but DON presented no

299 differences among plots (Table 1). Similarly, the cultivated plot presented a greater concentration

300 of ammonium than the other two plots $(\mathrm{P}<0.0001)$, but the highest values of nitrate and available

$301 \mathrm{P}$ were in the abandoned and the grassland plots, respectively $\left(\mathrm{P}<0.0001\right.$ for both $\mathrm{NO}_{3}$ and

302 available P; Table 1).

303 Nutrients within microbial biomass. The cultivated plot had higher $\mathrm{C}$ and $\mathrm{N}$ concentrations

304 within the microbial biomass $\left(\mathrm{P}<0.0001\right.$ for both $\mathrm{C}_{\text {mic }}$ and $\left.\mathrm{N}_{\text {mic }}\right)$, but did not differ from the

305 abandoned plot in terms of microbial P (Table 1). However, the grassland plot had higher $\mathrm{N}_{\text {mic }}$

306 concentration than the abandoned plot and, consequently, the $\mathrm{C}: \mathrm{N}$ and $\mathrm{C}: \mathrm{P}$ ratios of the microbial

307 biomass did not differ among plots, but the N:P ratio was highest in the cultivated plot $(\mathrm{P}=0.05)$.

308 Using the equation for $\mathrm{C}: \mathrm{N}$ and $\mathrm{C}: \mathrm{P}$ homeostasis $\left(\mathrm{H}^{\prime}\right)$, the soil microbial community did present

309 a strong elemental homeostasis for phosphorus acquisition in the three sites $\left(\mathrm{H}^{\prime}=6.25,9.35\right.$ and

31012.9 respectively for cultivated, grassland and abandoned plots). For nitrogen acquisition, 
311 however, the microbial community of the cultivated soil presented a weak homeostasis $\left(\mathrm{H}^{\prime}=\right.$

312 0.63), while the grassland (3.23) and abandoned plot (5.29) presented higher homeostasis.

313 Enzymatic activity. The grassland soil had higher specific phosphatase activity than the other

314 two managed plots $(\mathrm{P}<0.0001$; Table 1$)$. The DOC correlated positively with DOP, ammonium,

315 nutrients within microbial biomass and phosphanatase activity, while nitrate correlated

316 negatively with available $\mathrm{P}$ and phosphanatase activity (Table 2). The first two principal

317 components explained $74 \%$ of the total variance, in which $54 \%$ was explained by the first

318 component. In the first component, the cultivated plot differed statistically to the other two non-

319 cultivated plots, while all three plots were significantly different in the second component (Fig.

320 1).These results suggest that the difference between the cultivated plot and the other two plots

321 explained 54\% of the total variance in the soil nutrient dynamic. The dynamic forms of soil

322 nutrients strongly correlated with nutrients within microbial biomass and phosphatase activity as

323 determined by canonical analysis (Canonical $\mathrm{R}=0.98, \mathrm{P}<0.0001)$. The eigenvalue of root 1 was

3240.95 and $\mathrm{pH}$ and POD had the highest canonical weight in root 1.

Soil resistance and resilience

327 In general, the soil variables analyzed showed low resistance to agricultural management, since

328 the majority of the resistance values were negative or close to zero, with the exception of $\mathrm{pH}$ and

329 DON (Table 3). Similarly, the soil variables also had low resilience, because none of the values

330 was close to 1 (Table 3), which means that these soil variables were dissimilar to the grassland

331 soil. However, the $\mathrm{C}$ and $\mathrm{N}$ concentrations within the microbial biomass, DOC and DOP were

332 closer in value to 1 (above 0.5 ), suggesting that these soil variables were more resilient than the 
333 other soil variables analyzed (Table 3), although these values were insufficient to achieve

334 recovery of these soil variables after 30 years.

335

336 Soil bacteria composition

337 Composition of bacterial communities. A total of 111 sequences were obtained for the 338 grassland,107 sequences for the cultivated plot and 93 sequences for the abandoned site. In the 339 grassland, we obtained a clone library with 111 sequences, while the cultivated plot had 107

340 sequences and the abandoned plot had 93. In the grassland, the sequences were distributed 341 among12 phyla and 19 classes, while the cultivated plot sequences comprised 9 phyla and 14

342 classes, and those of the abandoned plot comprised 9 phyla and 12 classes. These results suggest 343 that the bacterial community of the grassland soil was distributed in higher phyla than was the 344 case in the other two managed plots. For example, Protobacteria was the more abundant bacteria 345 phylum in the three plots, accounting for $50 \%$ of the results in the grassland and the abandoned 346 plot, but representing only $35 \%$ in the cultivated plot (Figure 2). Similarly, Actinobacteria was

347 the second most dominant phylumin both the grassland and abandoned plot $(20 \%$ and $21 \%$,

348 respectively), but only represented $15 \%$ in the cultivated plot. The two most important

349 phototrophic phyla (Chloroflexi and Cyanobacteria) were not found in the cultivated plot, but

350 Cyanobacteria was found in both the grassland soil and abandoned plot (Fig. 2).

351 Diversity of bacterial communities. Rarefaction curve analysis showed that the cultivated plot

352 had the richest bacterial community, followed by the abandoned plot and finally the grassland

353 soil (Fig. 3). In addition, the cultivated plot had the highest expected OTUs by the Chao analyses

354 (659), while the abandoned plot had the lowest expected value of OTUs (179). The latter plot

355 also had the lowest values of Simpson and Shannon indices ( $D=0.025$ and $H=3.8$, respectively), 
356 suggesting that the bacterial community of the abandoned plot was dominated by fewer OTUs in

357 comparison with the bacterial communities in the cultivated plot and the grassland soil $(\mathrm{D}=0.04$,

$358 \mathrm{H}=4.4$ and $\mathrm{D}=0.013, \mathrm{H}=4.2$; respectively).

359 From the total of 307 sequences obtained for all sites, 223 OTUs were recognized at $97 \%$ of

360 similitude. The cultivated plot again had the highest number of OTUs (92), followed by

361 grassland (84 OTUs) and finally the abandoned plot with the lowest number of OTUs (59). The

362 three sites shared four OTUs corresponding to the Proteobacteria (Rhizobiales,

363 Pseudomonadales, Burkholderiales and Xanthomonadales). The abandoned plot shared two

364 OTUs with the other sites, but there were no OTUs shared between the grassland and the

365 cultivated plot. Finally, the grassland soil and abandoned plot presented higher similitude

366 between them relative to the cultivated plot, using the $16 \mathrm{~S}$ rRNA community composition at

$36797 \%$ similarity based on the Bray-Curtis algorithm.

369 DISCUSSION

\section{Soil nutrient dynamics}

371 In the Cuatro Cienegas basin (CCB), alfalfa production by flooding the fields threatens the

372 wetlands sustainability and contributes to the degradation of soil and vegetation system. The

373 results showed that the cultivated plot presented a lower soil $\mathrm{pH}$ than the other two sites, which

374 could be associated with the fertilization and continuous irrigation, it as has been reported in

375 other agriculture sites (Moore et al., 2000; Raiesi, 2004). Soil N fertilization mainly with

376 ammonium, as it is applied to the site of the present study, promotes nitrification by releasing $\mathrm{H}^{+}$

377 ions into the soil solution (Moore et al., 2000), while continuous irrigation increases the leaching

378 of salt through the soil profile (Raiesi, 2004). However, the cultivated plot presented higher 
379 concentrations of total $\mathrm{C}, \mathrm{N}$ and $\mathrm{P}$ than the other two plots. These increases are caused by

380 fertilization and by the particular crop under cultivation, with the latter mainly affecting the SOC

381 concentration. Perennial legumes, such as alfalfa, promote higher SOC accumulation in

382 comparison with the annual crops since they feature high root biomass production and require

383 low soil tillage (Franzluebbers, 2009; Sainju \& Lenssen, 2011; Bell et al., 2012; Yang et al.,

384 2013). Furthermore, the alfalfa plot had a greater availability of dissolved organic carbon (DOC),

385 which could be explained by higher organic matter input and soil water availability. These

386 conditions promoted depolymerization of organic molecules and mineralization of organic

387 nutrients mediated by the activity of heterotrophic microorganisms (Wardle, 1992; Vineela et al.,

388 2008). Associated with this higher activity of heterotrophic microorganisms, organic $\mathrm{N}$ is mainly

389 released as $\mathrm{NH}_{4}^{+}$and then immobilized within microbial biomass, as suggested by the $\mathrm{NH}_{4}^{+}$and

$390 \mathrm{~N}_{\text {mic }}$ values of the cultivated plot. All of these results suggest that the cultivated plot presented

391 higher soil nutrient transformations, mainly of $\mathrm{N}$, promoted by the availability of water and

392 nutrient fertilization, and thus the soil nutrient dynamics of this plot differ from the plots without

393 management, as suggested by the results of the PCA. In contrast, the low amount of soil organic

394 matter in the native grassland is consequence of low availability of soil water in the east-side of

395 CCB (Tapia-Torres et al., 2015a). The low water availability reduces plant productivity and in

396 consequence there is a lower input of organic matter input to the soil, as Tapia-Torres et al.

397 (2015b) reported for soils under desert scrub within CCB. Consequently, the activity of

398 microbial populations is constrained by low availability of organic carbon (Wardle, 1992).

399 The nutrients within microbial biomass and phosphatase activity are strongly affected by the

400 dynamics of soil nutrients as Canonical Analysis confirmed. While the cultivated plot presented

401 higher nutrient concentrations within microbial biomass than the other two plots, microbial C:N 
402 and C:P did not differ among plots. These results suggest that the soil microbial community had 403 different strategies for nutrient acquisition in order to equilibrate nutrient stoichiometry (Sterner $404 \&$ Elser, 2002). The soil microbial communities of the plots showed elemental homeostasis, with 405 the exception of the cultivated soil, in which $\mathrm{N}$ acquisition showed weak homeostasis, probably 406 in response to the constant fertilization with ammonium. Tapia-Torres et al. (2015a) also 407 reported a strong $\mathrm{N}$ and $\mathrm{P}$ homeostasis for two native grasslands within the CCB. These results 408 suggest that soil microbial communities adopt different strategies for nutrient acquisition, 409 including the production of eco-enzymes which clave the organic molecules for microbial 410 assimilation (Waring et al., 2014). Phosphatase is the main eco-enzyme that mineralizes organic 411 P molecules (Tabatabai \& Bremner, 1969). In our study site, the native grassland had higher 412 specific phosphatase activity, indicating that members of the soil microbial community in this 413 plot invest more in production of this enzyme than in growth, which suggests that this microbial 414 community is co-limited by $\mathrm{C}$ and $\mathrm{P}$ as reported before for the same study site by Tapia-Torres et 415 al. (2015a). Moreover, the microbial C:N:P ratio of the cultivated plot $(99: 33: 1)$ is wider than 416 that proposed by Cleveland and Liptzin (2007) for different terrestrial ecosystems (60:7:1), while 417 the non-managed plots are closer to this ratio (42:5:1 and 56:2:1 for the natural grassland and 418 abandoned plot, respectively). These results suggest that the agricultural management strongly 419 disrupts soil microbial activity and its homeostasis.

420 As expected, the sites under no current management were limited by water and DOC. At the 421 abandoned site, these conditions promoted the nitrification process, which is mediated by 422 autotrophic microorganisms that can use $\mathrm{NH}_{4}^{+}$as their energy source (Hart et al., 1994; Chen \& 423 Stark, 2000). The microbial N immobilization process was favored in the native grassland; this 
424 process promotes $\mathrm{N}$ conservation within the ecosystem, as previously reported for native

425 grassland in the CCB (Tapia-Torres et al., 2015b).

426

427 Soil bacteria composition

428 The agricultural land-use change affected the soil bacteria composition. Agricultural

429 management increased the numbers of OTUs and diversity indices associated with higher

430 availability of soil water and energy for microbial activity. Such increases due to agriculture

431 activity have been reported for other desert sites (Köberl et al., 2011; Wang et al., 2012).

432 However, the abandoned plot had lower OTUs and diversity indexes in comparison with the

433 other two plots, probably associated with more stressful soil conditions (i.e. higher salinity,

434 lower water and nutrient availability) as reported by Keshri et al. (2013) for desert soils.

435 The two dominant phyla from the three plots analyzed were Proteobacteria and Actinobacteria,

436 which are both very common in agricultural (Buckley \& Schmidt, 2003; Chaudhry et al., 2012)

437 and desert (Chanal et al., 2006; López-Lozano et al., 2012) soils. However, their relative

438 proportion differed among plots, especially in the case of the cultivated plot. Moreover, the two

439 most important phototrophic phyla (Chloroflexi and Cyanobacteria) were not found in the

440 cultivated plot, where $\mathrm{N}$ input and soil disruption selected against their presence. As expected,

441 Cyanobacteria were present in both the grassland soil and the abandoned plot, forming a desert

442 crust (Li et al., 2012). In contrast, the Acidobacteria were more abundant in the cultivated plot

$443(\mathrm{ca} .18 \%)$, while in the non-cultivated plot had decreased to $2 \%$. This Phylum is associated with

$444 \mathrm{pH}$ neutral or acid soils, such as the soils of the cultivated plot. The results suggest that

445 agricultural management has a strong effect on soil bacterial composition, because the

446 agricultural plot shared lower OTUs (only 4) with the plot under no management. Furthermore, 
447 according to the Bray-Curtis algorithm, the grassland soil and the abandoned plot had a higher

448 similitude between them relative to the cultivated plot. For example, in both the native grassland

449 and the abandoned plots, some extremophile OTUs were present, e.g., that associated with the

450 Phylum Deinococcus-Thermus, which is adapted to stressful soil conditions such as salinity, high

451 temperatures, aridity, etc. (Nienow, 2009); however, these OTUs were not presented in the

452 cultivated plot. These results suggest that some OTUs recover after abandonment of agricultural

453 management, although the soil bacteria community is not yet similar to that in the native

454 grassland even after more than 30 years since abandonment. One study has reported similar soil

455 bacteria in native vegetation and sites abandoned for over 45 years in agro-ecosystems of

456 Michigan State (Buckley \& Smith, 2003).

457 In soil microbial communities, microfungi are an important and diverse component of microbial

458 diversity, representing a large proportion of microbial diversity in soils (Fierer et al., 2007).

459 These microorganisms play an immense role in regulating energy and nutrient fluxes through

460 natural ecosystems, via their involvement in soil development, decomposition and uptake of

461 nutrients by plants (Dighton 1997) mainly phosphate uptake. Future studies should be aimed at

462 understanding the role of microfungi in soil nutrient cycling in this ecosystem. However, tagging

463 of ITS markers for soil fungi in CCB have been challenging, so there is still further research

464 needed in this field.

465 Soil resistance and resilience

466 All of the variables evaluated presented low resistance and resilience, suggesting that the native 467 grassland soil may be very vulnerable to agricultural transformation. The resilience of soil is 468 determined by its intrinsic characteristics, as well as by prevailing climatic conditions (Blanco-

469 Canqui \& Lal, 2010). For instance, soil with high organic matter content is more resilient, since 
470 organic compounds represent important reservoirs of energy and nutrients for both the soil

471 microbial community and plants (Bronick \& Lal, 2005). In addition, ecosystems in humid

472 climates are also more resilient than arid ecosystems because they are not constrained by water

473 availability. For example, the wet tropical ecosystem requires less than 10 years for recovery of

474 its vegetal community following perturbation, while the desert ecosystem requires at least 40

475 years (Lesschen et al., 2008; Wang et al., 2011). Our results suggest that the native grassland

476 presents slow recovery and this characteristic is critical for the design of alternative agricultural

477 management, as well as appropriate strategies for soil reclamation. This is important because the

478 rate of soil degradation is faster than that of soil restoration, which acts to increase the area of

479 degraded lands in these arid ecosystems.

480 The design of soil restoration practices is critical for $\mathrm{CCB}$, because the ecosystems within CCB

481 are very vulnerable to the disruption of nutrient dynamics, and the native species have low

482 competition capacity against invasive species under higher availability of resources (Souza et al.,

483 2006). This situation is critical for the soils of CCB, because they contain a high diversity of

484 native species that can face up the scarcity of nutrients, mainly P (Tapia-Torres et al., 2016). The

485 organic agriculture with low pesticide inputs and the use of native microbial strains with

486 different capabilities to use, transform and recycle the soil nutrients (i.e. phosphorus solubilizing

487 bacteria) could be the best solution for agriculture in this particular and highly diverse important

488 ecosystem. These agricultural practices not only will allow the maintenance of soil microbial

489 biodiversity but also will contribute to the soil conservation. Therefore, ensuring long-term

490 availability and accessibility to healthy soil, mainly for food security is a global challenge.

492 CONCLUSIONS 
493 Our results suggest that land-use change transforming native grassland into agricultural land

494 induces drastic modifications in the soil nutrient dynamics as well as in the bacterial community.

495 However, with the suspension of agricultural practices, some soil characteristics tend to slowly

496 recover their natural state.

497

498 Acknowledgements

499 We are thankful to Rodrigo Velázquez-Durán for assisting with chemical analysis and to Alberto

500 Valencia for assisting data analyses. We also thank Oscar Sánchez Liceaga, Héctor Castillo

501 González, the personnel of APFF Cuatro Cienegas (CONANP) and the people in charge of

502 Rancho Pozas Azules (PRONATURA) for permission to collect soil samples on their respective 503 properties.

504

505

506

507

508

509

510

511

512

513

514

515

\section{References}

Beheshti A, Raiesi F, Golchin A. 2012. Soil properties, C fractions and their dynamics in land useconversion from native forest to croplands in a northern Iran. Agriculture, Ecosystem \& Environment 148: 121-133. doi:10.1016/j.agee.2011.12.001.

Bell LW, Sparling B, Tenuta M, Entz MH. 2012. Soil profile carbon and nutrient stocks under long-term conventional and organic crop and alfalfa-crop rotations and re-established grassland. Agriculture Ecosystem \& Environment 158:156-163. doi:10.1016/j.agee.2012.06.006.

Blanco-Canqui H, Lal R. 2010. Soil resilence and conservation. In: Blanco-Canqui H, Lal R, ed. Principles of soil conservation and management, Springer, New York, USA, 425-447. 
516 Bremmer JM. 1996. Nitrogen-Total. In: Spark DL, Page AL, Summer ME, Tabatabai MA, $517 \quad$ Helmke PA, ed. Methods of Soil Analyses Part 3: Chemical Analyses, Soil Science Society of America, Madison, WI, USA, 1085-1121.

519

520

521

522

523

524

525

526

527

528

529

530

531

532

533

534

535

Bronick CJ, Lal R. 2005. Soil structure and management: a review. Geoderma 124: 3-22. doi:10.1016/j.geoderma.2004.03.005.

Brookes P, Landman A, Pruden G, Jenkinson D. 1985. Chloroform fumigation and the release of soil nitrogen: a rapid direct extraction method to measure microbial biomass nitrogen in soil. Soil Biology and Biochemistry 17: 837-842. doi:10.1016/0038-0717(85)90144-0.

Buckley DH, Schmidt TM. 2001. The structure of microbial communities in soil and the lasting impact of cultivation. Microbial Ecology 42: 11-21. doi: 10.1007/s002480000108

Buckle DH, Schmidt TM. 2003. Diversity and dynamics of microbial communities in soils from agro-ecosystems. Environmental Microbiology 5: 441-452. doi: 10.1046/j.14622920.2003.00404.x.

Chanal A, Chapon V, Benzerara K, Barakat M, Christen R, Achouak W, Barras F, Heulin T. 2006. The desert of Tataouine: an extreme environment that hosts a wide diversity of microorganisms and radio tolerant bacteria. Environmental Microbiology 8: 514-525. doi: 10.1111/j.1462-2920.2005.00921.x.

Chaudhry V, Rehman A, Mishra A, Chauhan PS, Nautiyal CC. 2012. Changes in bacterial community structure of agriculture land due to long-term organic and chemical amendments. Microbial Ecology 64: 450-460. doi: 10.1007/s00248-012-0025-y. 
536 Chen J, Stark JM. 2000. Plant species effects carbon and nitrogen cycling in a sagebrush-crested 537 wheatgrass soil. Soil Biology Biochemistry 32: 47-57. doi:10.1016/S0038$538 \quad \underline{0717(99) 00124-8 .}$.

539 Cleveland CC, Liptzin D. 2007. C:N:P stiochiometry in soil: is there a "Redfield ratio" for the 540 microbial biomass?. Biogeochemistry 85: 235-253. doi: 10.1007/s10533-007-9132-0.

541 Cole CV, Elliott ET, Hunt HW, Coleman DC. 1978. Trophic interactions in soils as they affect energy and nutrient dynamics. V. Phosphorus transformations. Microbial Ecology 4:

Colditz RR, Llamas RM, Ressl RA. 2014. Detecting change areas in Mexico between 2005 and 545 2010 using 250 m MODIS images. IEEE Journal on Selected Topics in Applied Earth Observation and Remote Sensing, 7: 3358-3372.

Dighton J. 1997. Nutrient cycling by saprotrophic fungi in terrestrial habitats. The Mycota, 4, 548 271-279.

Ding G, Piceno YM, Heuer H, Weinert N, Dohrmann AB, Carrillo A, Andersen GL, Castellanos T, Tebbe CC, Smalla K. 2013. Changes of soil bacteria diversity as a consequence of agriculture land use in a semi-arid ecosystem. PloS one 8: e59497. doi:

D'Odorico P, Bhattachan A, Davis KF, Ravi S, Runyan CW. 2013. Global desertification: 10.1371/journal.pone.0059497. drivers and feedback. Advances in Water Resources 51: 326-344. doi:10.1016/j.advwatres.2012.01.013.

556 Eivazi F, Tabatabai MA. 1977. Phosphatases in soils. Soil Biology and Biochemistry 9: 167-172. 
557 Ewing B, Green P. 1998. Base-calling of automated sequencer traces using phred. II. Error 558 probabilities. Genome Research 8:186-194.

559

560

561

562

563

564

565

566

567

568

569

570

571

572

573

574

575

576

577

Fierer N, Bradford MA, Jackson RB. 2007. Toward an ecological classification of soil bacteria. Ecology 88: 1354-1364. doi: 10.1890/05-1839.

Franzluebbers AJ. 2009. Achieving soil organic carbon sequestration with conservation agricultural systems in the southeastern United States. Soil Science Society of American Journal 74: 347-357. doi:10.2136/sssaj2009.0079.

García-Orenes F, Morugán-Coronado A, Zornoza R, Scow K. 2013. Changes in soil microbial community structure influenced by agricultural management practices in a Mediterranean Agro-Ecosystem. PLoS ONE 8(11): e80522. DOI: 10.1371/journal.pone.0080522.

Haas BJ, Gevers D, Earl AM, Feldgarden M, Ward DV, Giannoukos G, Ciulla D, Tabba D, Highlander SK, Sodergren E, Methé B, DeSantis TZ, The Human Microbiomes Consortium, Petrosino JF, Knight R, Birren BW. 2011. Chimeric 16S rRNA sequence formation and detection in Sanger and 454-pyrosequenced PCR amplicons. Genome Research 21: 494-504. doi: 10.1101/gr.112730.110

Hart S, Nason GE, Myrlod D, Perry D.A. 1994. Dynamic of gross nitrogen transformations in an old-growth forest: the carbon connection. Ecology 75: 880-891. doi: 10.2307/1939413.

Huffman EN. 1977. Performance of a new automatic carbon dioxide coulometer. Microchemical Journal 2, 567-573.

INEGI, Instituto Nacional de Estadística y Geografía. 2011. Anuario Estadístico de Coahuila de Zaragoza. INEGI, México. 
578 IUSSS Working Group WRB. 2007. World Reference Base for Soil Resources 2006, first update 579 2007. World Soil Resources Reports No. 103, FAO, Rome.

580

581

582

583

584

585

586

587

588

589

590

591

592

593

594

595

596

597

Jangid K, Williams MA, Franzluebbers AJ, Sanderlin JS, Reeves JH, Jenkins MB, Endale DM, Coleman DC, Whitman WB. 2008. Relative impacts of land-use, management intensity and fertilization upon soil microbial community structure in agricultural systems. Soil Biology and Biochemistry 40: 2843-2853. doi:10.1016/j.soilbio.2008.07.030.

Joergensen RG. 1996. The fumigation-extraction method to estimate soil microbial biomass: Calibration of the $\mathrm{K}_{\mathrm{EC}}$ value. Soil Biology and Biochemistry 28: 25-31. doi: $\underline{10.1016 / 0038-0717(95) 00102-6 .}$

Joergensen RG, Mueller T. 1996. The fumigation-extraction method to estimate soil microbial biomass: calibration of de $\mathrm{K}_{\mathrm{EN}}$ value. Soil Biology and Biochemistry 28: 33-37. doi:10.1016/0038-0717(95)00101-8.

Jones DL, Willett VB. 2006. Experimental evaluation of methods to quantify dissolved organic nitrogen (DON) and dissolved organic carbon (DOC) in soil. Soil Biology and Biochemistry 38: 991-999. doi:10.1016/j.soilbio.2005.08.012.

Keshri J, Mody K, Jha B. 2013. Bacterial community structure in a semi-arid haloalkaline soil using culture independent method. Geomicrobiology Journal 30: 517-529.

Köberl M, Müller H, Ramadan EM. Berg G. 2011. Desert farming benefits from microbial potential in arid soils and promotes diversity and plant health. Plos one 6: 1-9. doi: 10.1371/journal.pone.0024452. 
598 Lathja K, Driscoll CT, Jarrell WM, Elliott ET. 1999. Soil phosphorus: characterization and total 599 element analysis. In: Robertson GP, Coleman DC, Bledsoe CS, Sollins P, ed. Standard 600 soil methods for long-term ecological research, Oxford University Press, New York, $601 \quad$ USA, 115-142.

602 Lepers E, Lambin EF, Janetos AC, De Fries R, Archad F, Ramankutty N, Scholes RJ. 2005. A 603 604 synthesis of rapid land-cover change information for the 1981-2000 period. BioScience 55: 115-124. doi: 10.1641/0006-3568(2005)055[0115:ASOIO

605

606

607

608

609

610

611

612

613

614

615

616

617

618

Lesschen JP, Cammeraat LH, Kooijman AM, Wesemael B. 2008. Development of spatial heterogeneity in vegetation and soil properties after land abandonment in a semi-arid ecosystem. Journal of Arid Environment 72: 2082-2092. doi:10.1016/j.jaridenv.2008.06.006.

Li XR, Zhang P, Su YG, Jia RL, 2012. Carbon fixation by biological soil crusts following revegetation of sand dunes in arid desert regions of China: A four-year field study. Catena 97:119-126. doi:10.1016/j.catena.2012.05.009.

López-Lozano NE, Eguiarte LE, Bonilla-Rosso G, García-Oliva F, Martinez-Piedragil C, Rooks C, Souza V. 2012. Bacteria communities and nitrogen cycle in the gypsum soil in CuatroCienegas Basin, Coahuila: A Mars analogue. Astrobiology 12: 699:-709. doi: 10.1089/ast.2012.0840.

Lupwayi NZ, Rice WA, Clayton GW. 1998. Soil microbial diversity and community structure under wheat as influenced by tillage and crop rotation. Soil Biology and Biochemistry 30: 1733-1741. doi:10.1016/S0038-0717(98)00025-X. 
619 McKee JW, Jones NW, Long LE. 1990. Stratigraphy and provenance of strata along the San 620 Marcos fault, central Coahuila, Mexico. Geological Society of America Bulletin 102: 593614. doi: 10.1130/0016-7606(1990)102<0593:SAPOSA>2.3.CO;2.

622 McLauchlan KK. 2006. The nature and longevity of agriculture impacts on soil carbon and 623 nutrients: A review. Ecosystems 9: 1364-1382. doi: 10.1007/s10021-005-0135-1.

624

625

626

627

628

629

630

631

632

633

634

635

636

637

638
Moore JM, Klose S, Tabatabai MA. 2000. Soil microbial biomass carbon and nitrogen as affected by cropping systems. Biology and Fertility of Soils 31: 200-210.

Murphy J, Riley JP. 1962. A modified single solution method for the determination of phosphate in natural waters. Analytica Chimica Acta 27: 31-36.

Murty D, Kirschbaum MUF, McMurtrie RE, McGilvray H. 2002. Does conversion of forest to agricultural land change soil carbon and nitrogen? A review of the literature. Global Change Biology 8: 105-123. doi: 10.1046/j.1354-1013.2001.00459.x.

Nienow J. 2009. Extremophiles: dry environments (including cryptoendoliths). In: Schaechter M, ed. Encyclopedia of Microbiology, Elsevier, Oxford, UK, 159-173.

Orwin KH, Wardle DA, 2004. New indices for quantifying the resistence and resilience of soil biota to exogenous disturbances. Soil Biology and Biochemistry 36: 1907-1912. doi:10.1016/j.soilbio.2004.04.036.

Pan C, Liu C, Zhao H, Wang Y. 2012. Changes of soil physical-chemical properties and enzyme activities in relation to grassland salinization. European Journal of Soil Biology 55: 1319. 
639 Perroni Y, García-Oliva F, Souza V. 2014. Plant species identity and soil P forms in an 640 oligotrophic grassland-desert scrub system. Journal of Arid Environments 108: 29-37. $641 \quad$ doi:10.1016/j.jaridenv.2014.04.009.

642 Pimm SL. 1984. The complexity and stability of ecosystems. Nature 307: 321-326.

643 Purdy KJ, Embley TM, Takii S, Nedwell DB. 1996. Rapid Extraction of DNA and rRNA from 644 sediments by a novel hydroxyapatite spin-column Method. Applied. Environmetal $645 \quad$ Microbiology 62: 3905-3907.

646 Raiesi F. 2004. Soil properties and N application effects on microbial activities in two winter wheat cropping systems. Biology and Fertility of Soils 40: 88-92. Doi: 10.1007/s00374004-0741-7.

Rey-Benayas JM, Bullock JM. 2012. Restoration of biodiversity and ecosystem services on agricultural land. Ecosystems 15: 883-899. doi: 10.1007/s10021-012-9552-0

Reynolds JF, Smith DMS, Lambin EF, Turner BL, Mortimore M, Batterbury SPJ, Downing TE, 652 Dowlatabadi H, Fernández RJ, Herrick JE, Huber-Sannwald E, Juang H, Leemans R, Lynam T, Maestre FT, Ayarza M, Walker B. 2007. Global desertification: building a science for dryland development. Science 316: 847-851. doi: 10.1126/science1131634.

655

656

657

658

659

Robertson PG, Coleman DC, Bledsoe CS, Sollins P. 1999. Standard soil methods for long-term ecological research (LTER), University Press, Oxford, New York. 
660 Sainju UM, Lenssen AW. 2011. Dryland soil carbon under alfalfa and durum-forage cropping 661 sequences. Soil Tillage Research 113: 30-37. doi:10.1016/j.still.2011.02.002.

662 Schloss PD, Handelsman J. 2005. Introducing DOTUR, a computer program for defining

663

664

665

666

667

668

669

670

671

672

673

674

675

676

677

678

679

680 operational taxonomic units and estimating species richness. Applied Environmental Microbiology 71: 1501-1506. doi: 10.1128/AEM.71.3.1501-1506.2005.

Schloss PD, Westcott SL, Ryabin T, Hall JR, Hartmann M, Hollister EB, Lesniewski RA, Oakley BB, Parks DH, Robinson CJ, Sahl JW, Stres B, Thallinger GG, Van Horn, DJ, Weber CF. 2009. Introducing mothur: open- source, platform-independent, communitysupported soft- ware for describing and comparing microbial communities. Applied Environmental. Microbiology 75: 7537-7541. doi: 10.1128/AEM.01541-09.

Souza V, Esponosa_Asuar L, Escalante AE, Eguiarte LE, Farmer J, Forney L, Lloret L, Rodríguez-Martínez JM, Soberon X, Dirzo R, Elser JJ. 2006. An endangered oasis of aquatic microbial biodiversity in the Chihuahuan Desert. Proceedings of the National Academy of Sciences 103: 6565-6570. doi: 10.1073/pnas.0601434103.

Six J, Elliott ET, Paustian K. 1999. Aggregate and soil organic matter dynamics under conventional and no-tillage systems. Soil Science Society of America Journal 63: 13501358. doi: 10.2136/sssaj1999.6351350x.

Sterner RW, Elser JJ. 2002. Ecological Stoichiometry: the Biology of Elements from Molecules to the Biosphere. PrincetonUniversity Press, Princeton, NJ.

Tabatabai MA, Bremner JM. 1969. Use of p-Nitrophenyl phosphate for assay of soil phosphatase activity. Soil Biology and Biochemistry 1: 301-307. doi:10.1016/0038-0717(69)90012-1. 
681 Tapia-Torres Y, García-Oliva F. 2013. La disponibilidad del fósforo es producto de la actividad 682 bacteriana en el suelo en ecosistemas oligotróficos: una revisión crítica. Terra683 Latinoamericana 31: 231-242.

684 Tapia-Torres Y, Elser JJ, Souza V, García-Oliva F. 2015a. Ecoenzymatic stiochiometry at the 685 extremes: How microbes cope an ultra-oligotrophic desert soil. Soil Biology and 686 Biochemistry 87: 34-42. Doi: 10.1016/j.soilbio.2015.04.007

687

688

689

690

691

692

693

694

695

696

697

698

699

700
Tapia-Torres Y, López-Lozano NE, Souza V, García-Oliva F. 2015b. Vegetation-soil system controls soil mechanisms for nitrogen transformations in an oligotrophic Mexican desert. Journal of Arid Environments 114: 62-69. doi: 10.1016/j.jaridenv.2014.11.007.

Tapia-Torres Y, Rodríguez-Torres MD, Islas A, Elser J, Souza V, Olmedo-Álvarez G GarcíaOliva F. 2016. How to live with phosphorus scarcity in soil and sediment: lessons from bacteria. Applied and Environmental Microbiology 82: 00-00. Doi: 10.1128/AEM.00160-16.

Tiessen H, Moir JO. 1993. Characterization of available P by sequential extraction. In: Carter MR, Gregorich EG, ed. Soil sampling and methods of analysis. CRC Press, New York, USA, 75-85.

Trasar-Cepeda C, Leirós MC, Seoane S, Gil-Sotres F. 2008. Biochemical properties of soils under crop rotation. Applied Soil Ecology 39, 133-143. doi:10.1016/j.apsoil.2007.12.003. 
701 Vance ED, Brookes AC, Jenkinson DS. 1987. An extraction method for measuring soil microbial 702 biomass C. Soil Biology and Biochemistry 19: 703-707.

703 Velez P, Gasca-Pineda J, Rosique-Gil E, Eguiarte LE, Espinosa_Asuar L, Souza V. 2016.

704 Microfungal oasis in an oligotrophic desert: diversity patterns and community structure in

705

706

707

708

709

710

711

712

713

714

715

716

717

718

719 three freshwater systems of Cuatro Ciénegas, Mexico. Peer J 4:e2061; DOI 10.7717/peerj.2064.

Vineela C, Wani SP, Srinivasarao C, Padmaja B, Vittal KPR. 2008. Microbial properties of soils as affected by cropping and nutrient management practices in several long-term manorial experiments in the semi-arid tropics of India. Applied Soil Ecology 40: 165-173. doi:10.1016/j.apsoil.2008.04.001.

Von Ende CN. 1993. Repeated measures analysis: growth and other time-dependent measures. In: Scheiner SM, Gurevitch J, ed. Design and analysis of ecological experiments. Chapman and Hall, New York, USA, pp113-117.

Waldrop MP, Balser TC, Firestone MK. 2000. Linking microbial community composition to function in a tropical soil. Soil Biology and Biochemistry 32: 1837-1846. doi:10.1016/S0038-0717(00)00157-7.

Wang B, Liu G, Xue S, Zhu B. 2011. Changes in soil physic-chemical and microbiological properties during natural succession on abandoned farmland in the Loess Plateau. Environmental Earth Science 62: 915-925. doi: 10.1007/s12665-010-0577-4. 
720 Wang B, Zhang C, Liu J, Zeng X, Li F, Wu Y, Lin X, Xiong ZQ, Xu J, Jia ZJ. 2012. Microbial

721

722

723

724

725

726

727

728

729

730

731

732

733

734

735 community changes along a land-use gradient of desert soil origin. Pedosphere 22: 593603. doi:10.1016/S1002-0160(12)60044-7.

Wardle DA. 1992. A comparative assessment of factors which influence microbial biomass carbon and nitrogen levels in soil. Biological Reviews 67: 321-358. doi: 10.1111/j.1469185X.1992.tb00728.x.

Waring BG, Weintraub SR, Sinsabaugh RL. 2014. Ecoenzymatic stiochiometry of microbial nutrient acquisition in tropical soils. Biogeochemistry 117: 101-113. doi: 10.1007/s10533-013-9849-x.

Yang R, Su Y, Gan Y, Du M, Wang M. 2013. Field-scale spatial distribution characteristics of soil nutrients in a newly reclaimed Sandy cropland in the Hexi Corridor of Northwest China. Environmental Earth Science 70: 2987-2996. doi: 10.1007/s12665-013-2356-5.

Zeleke TB, Grevers MCJ, Si BC, Mermut AR, Beyene S. 2004. Effect of residue incorporation on physical properties of the surface soil in the South Central Rift Basin of Etiopia. Soil Tillage Research 77: 35-46. doi:10.1016/j.still.2003.10.005. 


\section{Table $\mathbf{1}$ (on next page)}

Means (standard error) of available, dissolved, microbial forms of $\mathrm{C}, \mathrm{N}$ and $\mathrm{P}$ and Specific phophonatase activity (SPA) of soil from an agricultural gradient at Cuatro Ciénegas Basin.

Values immediately followed by a different letter indicate that the means are significantly different $(P \leq 0.05)$ among agricultural gradient plots. EC: Electrical conductivity; TOC: total organic Carbon, TN: total Nitrogen; TP: total Phophorus; DOC: dissolved organic Carbon, DON: dissolved organic nitrogen; DOP: dissolved organic phosphorus; $\mathrm{NH}_{4}^{+}$: ammonium, $\mathrm{NO}_{3}$ : nitrate; $\mathrm{HPO}_{4}:$ : orthophosphate; $\mathrm{C}_{\text {mic }}$ : microbial carbon; $\mathrm{N}_{\text {mic }}$ : microbial nitrogen; $\mathrm{P}_{\text {mic }}$ : microbial phosphorus; SPA: specific phosphatase activity. 


\begin{tabular}{|c|c|c|c|}
\hline & Grassland & Cultivated Plot & Abandoned Plot \\
\hline $\mathrm{pH}$ & $8.5(0.03)^{\mathrm{B}}$ & $7.9(0.04)^{\mathrm{C}}$ & $8.8(0.04)^{\mathrm{A}}$ \\
\hline $\mathrm{EC}\left(\mathrm{mS} \mathrm{m}^{-1}\right)$ & $8.7(0.6)^{\mathrm{B}}$ & $3.4(0.1)^{\mathrm{C}}$ & $15.6(3.0)^{\mathrm{A}}$ \\
\hline TOC $\left(\mathrm{mg} \mathrm{g}^{-1}\right)$ & $5.97(0.71)^{\mathrm{B}}$ & $21.50(1.17)^{\mathrm{A}}$ & $9.54(1.49)^{\mathrm{B}}$ \\
\hline $\mathrm{TN}\left(\mathrm{mg} \mathrm{g}^{-1}\right)$ & $0.63(0.06)^{\mathrm{C}}$ & $2.61(0.07)^{\mathrm{A}}$ & $1.13(0.05)^{\mathrm{B}}$ \\
\hline $\mathrm{TP}\left(\mathrm{mg} \mathrm{g}^{-1}\right)$ & $0.094(0.01)^{\mathrm{C}}$ & $0.768(0.04)^{\mathrm{A}}$ & $0.53(0.02)^{\mathrm{B}}$ \\
\hline $\mathrm{C}: \mathrm{N}$ & $9.3(0.3)$ & $8.3(0.6)$ & $8.3(1.2)$ \\
\hline $\mathrm{C}: \mathrm{P}$ & $64(5)^{\mathrm{A}}$ & $29(2)^{\mathrm{B}}$ & $18(3)^{\mathrm{C}}$ \\
\hline $\mathrm{N}: \mathrm{P}$ & $6.9(0.5)^{\mathrm{A}}$ & $3.5(0.2)^{\mathrm{B}}$ & $2.1(0.1)^{\mathrm{C}}$ \\
\hline DOC $(\mu \mathrm{g} g-1)$ & $9(2)^{\mathrm{C}}$ & $116(9)^{\mathrm{A}}$ & $39(7)^{\mathrm{B}}$ \\
\hline DON ( $\mu \mathrm{g} g-1)$ & $7.7(0.8)$ & $6.6(0.2)$ & $13.6(3.5)$ \\
\hline DOP $(\mu \mathrm{g} g-1)$ & $1.1(0.3)^{\mathrm{B}}$ & $14.6(0.2)^{\mathrm{A}}$ & $2.1(0.8)^{\mathrm{B}}$ \\
\hline $\mathrm{NH}_{4}^{+}(\mu \mathrm{g} g-1)$ & $1.64(0.08)^{\mathrm{B}}$ & $3.51(0.40)^{\mathrm{A}}$ & $1.55(0.13)^{\mathrm{B}}$ \\
\hline $\mathrm{NO}_{3}^{-}(\mu \mathrm{gg}-1)$ & $0^{\mathrm{C}}$ & $4.91(0.41)^{\mathrm{B}}$ & $18.16(1.30)^{\mathrm{A}}$ \\
\hline $\mathrm{HPO}_{4}^{-}(\mu \mathrm{g} g-1)$ & $0.096(0.015)^{\mathrm{A}}$ & $0.010(0.002)^{\mathrm{B}}$ & $0.004(0.001)^{\mathrm{B}}$ \\
\hline $\mathrm{C}_{\text {mic }}(\mu \mathrm{gg} \mathrm{g}-1)$ & $108(12)^{\mathrm{B}}$ & $451(68)^{\mathrm{A}}$ & $145(29)^{\mathrm{B}}$ \\
\hline $\mathrm{N}_{\text {mic }}(\mu \mathrm{g} g-1)$ & $14(1.3)^{\mathrm{B}}$ & $95(23.6)^{\mathrm{A}}$ & $4(1.0)^{\mathrm{C}}$ \\
\hline$P_{\text {mic }}(\mu \mathrm{gg}-1)$ & $1.95(0.41)^{\mathrm{B}}$ & $5.88(1.21)^{\mathrm{A}}$ & $3.20(0.48)^{\mathrm{AB}}$ \\
\hline $\mathrm{C}_{\mathrm{mic}}: \mathrm{N}_{\mathrm{mic}}$ & $8.1(0.9)$ & $9.00(2.3)$ & $23(6.9)$ \\
\hline $\mathrm{C}_{\text {mic }}: \mathrm{P}_{\text {mic }}$ & $42(9)$ & $99(17)$ & $56(13)$ \\
\hline $\mathrm{N}_{\text {mic }}: \mathrm{P}_{\text {mic }}$ & $5.3(1.1)^{\mathrm{A}}$ & $33.2(16.4)^{\mathrm{B}}$ & $1.7(0.3)^{\mathrm{A}}$ \\
\hline SPA & $1.50(0.44)^{\mathrm{A}}$ & $0.57(0.08)^{\mathrm{B}}$ & $0.46(0.27)^{\mathrm{B}}$ \\
\hline$\left(\mu \mathrm{m} \mathrm{mgC}_{\mathrm{mic}}{ }^{-1} \mathrm{~h}^{-1}\right)$ & & & \\
\hline
\end{tabular}

2 


\section{Table 2 (on next page)}

Pearson correlation coefficients for available nutrients and nutrients within microbial biomass in soil from agricultural gradient at Cuatro Cienegas Basin.

*: means significant correlation at $P \leq 0.05$. DOC: dissolved organic Carbon, DON: dissolved organic nitrogen; DOP: dissolved organic phosphorus; $\mathrm{NH}_{4}{ }^{+}$: ammonium, $\mathrm{NO}_{3}:$ nitrate; $\mathrm{HPO}_{4}$ : orthophosphate; $\mathrm{C}_{\text {mic }}$ : microbial carbon; $\mathrm{N}_{\text {mic }}$ : microbial nitrogen; $\mathrm{P}_{\text {mic }}$ : microbial phosphorus; SPA: specific phosphatase activity. 


\begin{tabular}{|c|c|c|c|c|c|c|c|c|c|c|c|}
\hline & pH & DOC & DON & DOP & $\mathrm{NH}_{4}{ }^{*}$ & $\mathrm{NO}_{3}^{-}$ & $\mathrm{HPO}_{4}^{-}$ & $\mathbf{C}_{\text {mic }}$ & $\mathbf{N}_{\text {mic }}$ & $\mathbf{P}_{\text {mic }}$ & SPA \\
\hline pH & 1 & & & & & & & & & & \\
\hline DOC & $-0.70^{*}$ & 1 & & & & & & & & & \\
\hline DON & $0.46^{*}$ & -0.12 & 1 & & & & & & & & \\
\hline DOP & $-0.85^{*}$ & $0.88^{*}$ & $-0.37^{*}$ & 1 & & & & & & & \\
\hline $\mathbf{N H}_{4}{ }^{+}$ & $-0.68^{*}$ & $0.65^{*}$ & -0.23 & $0.72 *$ & 1 & & & & & & \\
\hline $\mathrm{NO}_{3}^{-}$ & $0.59 *$ & -0.01 & $0.46^{*}$ & -0.19 & -0.21 & 1 & & & & & \\
\hline $\mathrm{HPO}_{4}^{-}$ & 0.09 & $-0.51^{*}$ & -0.17 & -0.44 & -0.27 & $-0.61 *$ & 1 & & & & \\
\hline $\mathbf{C}_{\text {mic }}$ & $-0.68^{*}$ & $0.79 *$ & -0.24 & $0.74 *$ & $0.70^{*}$ & -0.09 & -0.32 & 1 & & & \\
\hline $\mathbf{N}_{\text {mic }}$ & $-0.70^{*}$ & $0.52 *$ & -0.22 & $0.66^{*}$ & $0.67^{*}$ & -0.18 & -0.20 & $0.44 *$ & 1 & & \\
\hline $\mathbf{P}_{\text {mic }}$ & $-0.41^{*}$ & $0.68 *$ & -0.21 & $0.57^{*}$ & $0.39 *$ & -0.01 & -0.30 & $0.62 *$ & 0.15 & 1 & \\
\hline SPA & $-0.88^{*}$ & $0.65^{*}$ & $-0.40^{*}$ & $0.84 *$ & $-0.76^{*}$ & $-0.52 *$ & -0.11 & $0.64 *$ & $0.62 *$ & 0.30 & 1 \\
\hline
\end{tabular}




\section{Table 3(on next page)}

Mean values ( \pm standard error) of the resistance and resilience values of nutrient parameters from an agricultural gradient at Cuatro Cienegas Basin.

DOC: dissolved organic Carbon, DON: dissolved organic nitrogen; DOP: dissolved organic phosphorus; $\mathrm{NH}_{4}^{+}$: ammonium, $\mathrm{NO}_{3}^{-}$: nitrate; $\mathrm{HPO}_{4}^{-}$: orthophosphate; $\mathrm{C}_{\text {mic }}$ : microbial carbon; $\mathrm{N}_{\text {mic }}$ : microbial nitrogen; $\mathrm{P}_{\text {mic }}$ : microbial phosphorus; SPA: specific phosphatase activity. 
1

2

\begin{tabular}{ccc}
\hline Variable & Resistance & Resilience \\
\hline $\mathbf{p H}$ & $0.88( \pm 0.01)$ & $0.20( \pm 0.12)$ \\
$\mathbf{D O C}$ & $-0.81( \pm 0.06)$ & $0.61( \pm 0.06)$ \\
$\mathbf{D O N}$ & $0.54( \pm 0.08)$ & $-0.28( \pm 0.18)$ \\
$\mathbf{D O P}$ & $-0.84( \pm 0.04)$ & $0.81( \pm 0.06)$ \\
$\mathbf{N H}_{4}{ }^{+}$ & $0.04( \pm 0.15)$ & $0.42( \pm 0.16)$ \\
$\mathbf{N O}_{\mathbf{3}^{-}}$ & $-1.00( \pm 0.00)$ & $-0.57( \pm 0.03)$ \\
$\mathbf{H P O}_{\mathbf{+}}{ }^{+}$ & $0.08( \pm 0.02)$ & $-0.04( \pm 0.02)$ \\
$\mathbf{C}_{\text {mic }}$ & $-0.43( \pm 0.09)$ & $0.56( \pm 0.13)$ \\
$\mathbf{N}_{\text {mic }}$ & $-0.45( \pm 0.16)$ & $0.56( \pm 0.15)$ \\
$\mathbf{P}_{\text {mic }}$ & $-0.28( \pm 0.17)$ & $0.37( \pm 0.13)$ \\
$\mathbf{S P A}$ & $-0.06(0.10)$ & $0.25( \pm 0.12)$ \\
\hline
\end{tabular}


Figure 1

Principal Component Analysis of dynamic nutrient forms from an agricultural gradient at Cuatro Cienegas Basin.

JPEG file

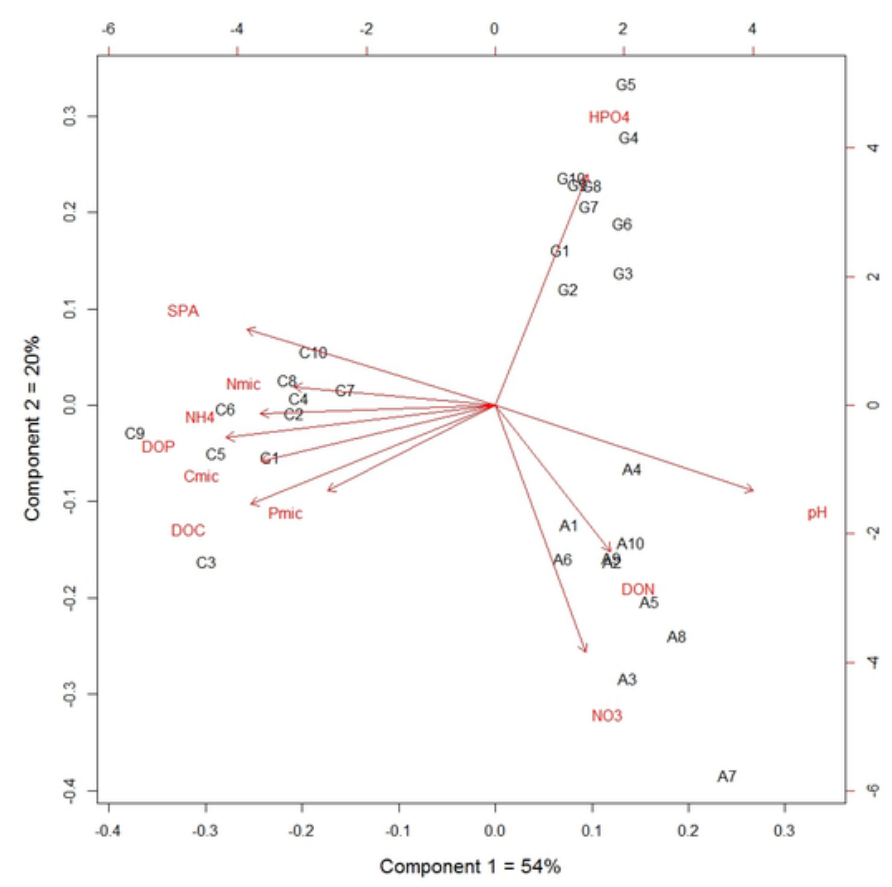




\section{Figure 2}

Taxonomic distribution of the 16 rRNA gene sequences obtained from clone libraries of an agricultural gradient at Cuatro Cienegas Basin.

JPG file

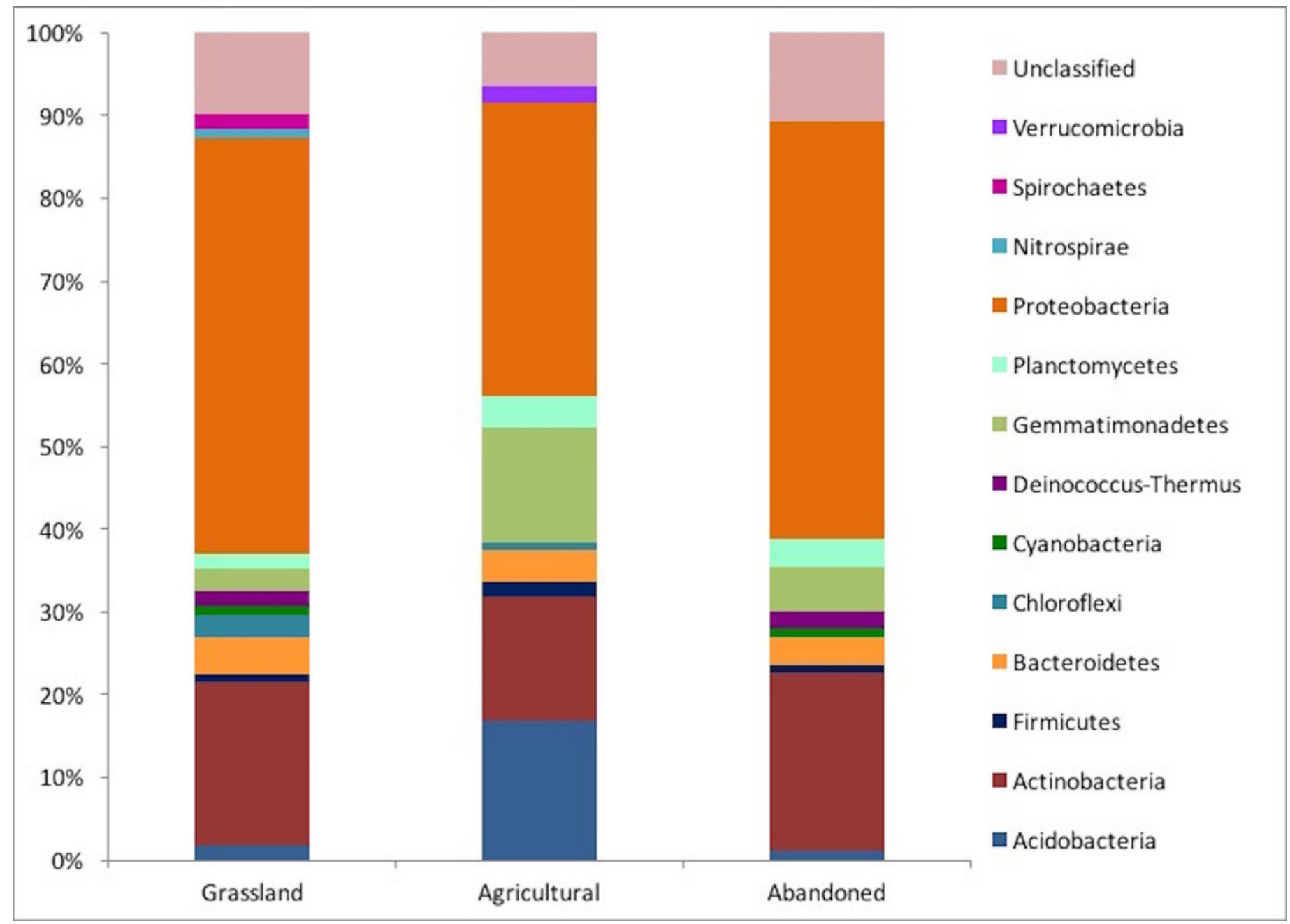


Figure 3

Rarefaction curves of an agricultural gradient at CuatroCienegasBasin. OTUs were determined at $97 \%$ sequence identity.

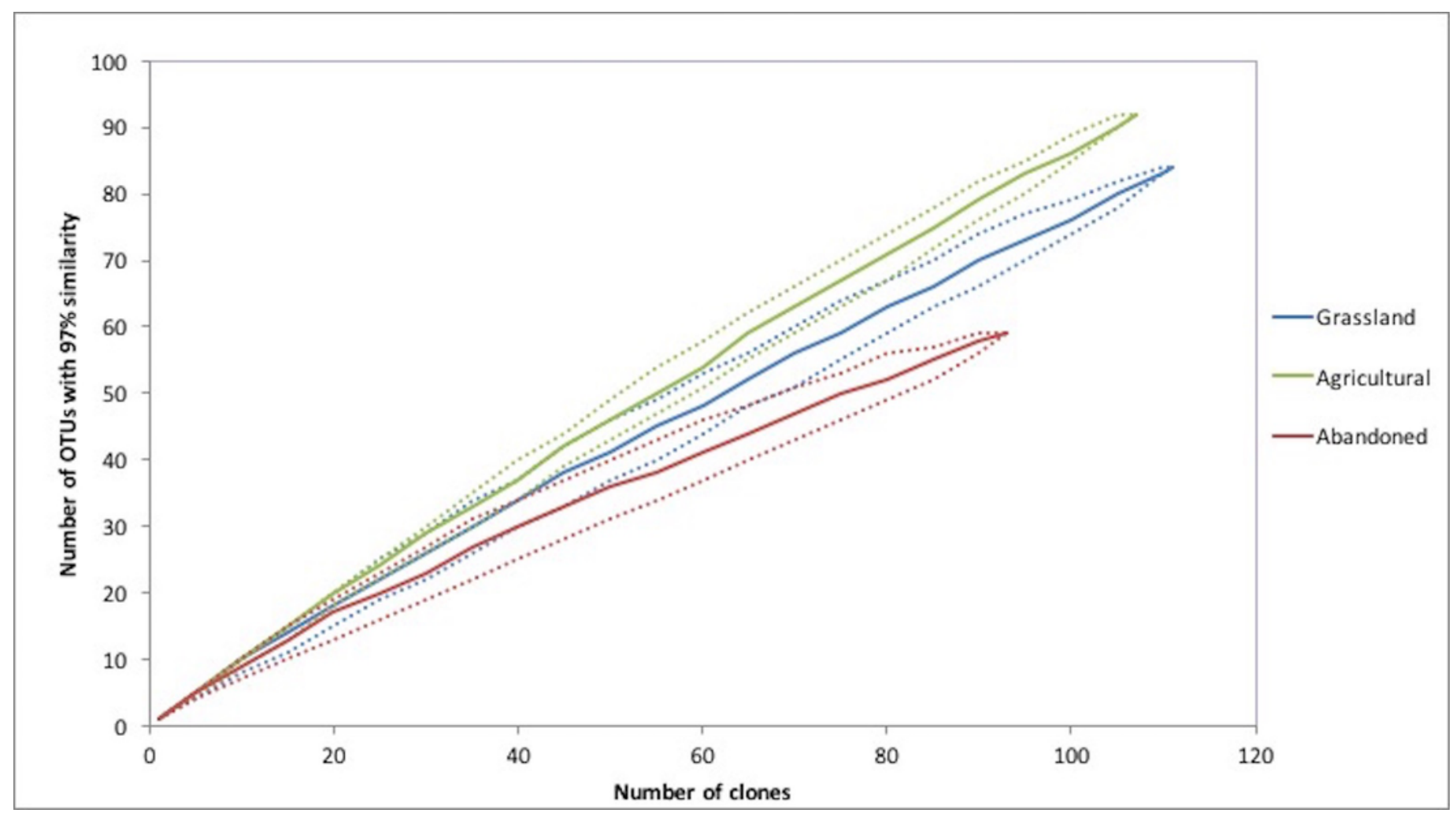

